\author{
A.Sh. Kazhikenova, D.B. Alibiyev, A.B. Seitimbetova, A.S. Smailova \\ E.A. Buketov Karaganda State University, Kazakhstan \\ (E-mail: aigul-kazhikenova@mail.ru)
}

\title{
Application of cluster-associative model for calculation of kinematic viscosity of metal melts
}

\begin{abstract}
Metal melts are often used in the national economy and industry. Therefore the study of the physicochemical properties of metals is given great attention. Especially researchers pay great attention to the study of viscosity, since viscosity is of great practical importance in metallurgy. Studying the viscosity of molten metal, at the same time, is essential scientific interest, since viscosity is the most structurally sensitive characteristic of the melt. The study of viscosity through experiment is somewhat difficult because many metals melt at very high temperatures. It is difficult to create such conditions without special equipment. Therefore many researchers are looking for additional development based on alternative approaches to understanding viscosity. The authors in their article consider a new concept of randomized particles and on this basis propose a cluster-associate model for calculating viscosity without conducting an experiment. The authors give examples of calculating the kinematic viscosity of some metals according to the model proposed in this paper. The results we received show that the proposed model allows us to calculate the viscosity even at very high temperatures. A comparison of the obtained results with experimental data shows the functionality of the proposed model. The proposed model can be used to calculate the viscosity of liquid metals in a wide temperature range. The article also shows the possibility of using this model for calculating the activation energy of a viscous melt flow.
\end{abstract}

Keywords: viscosity, chaotized particles, the degree of clusters association, cluster-associated model, liquid metals, reference point, crystal-moving particles, the temperature dependences of the viscosity.

\section{Introduction}

The viscosity, which is the main characteristic of the liquid is unable to be strictly express in theoretical terms based on different calculations of binding forces of particles, i.e. structural factors. The staff of Chemical and Metallurgical Institute (Karaganda) has developed the concept of chaotized particles by applying the Boltzmann law [1].

According to this approach all three aggregate states of matter are considered from a unified point of view on its unstructured component, that is, in all three states of matter there are crystal-like, liquid-like and vaporlike particles.

Earlier in the article "Efficiency of applying cluster-associated model of viscosity of liquid metals" [2] 3 models of viscosity of liquid metals were given depending on the content of randomized particles.

Equation (1) represents the temperature dependence of viscosity with adjustment to crystal-mobile particles:

$$
v_{1}=v_{r} T_{r} / T,
$$

where $v_{r}$ and $T_{r}$ - are kinematic viscosity and absolute temperature correspondingly for a certain reference point, in principle, arbitrarily chosen as the most reliable experimental determination.

Equation (2) represents the temperature dependence of viscosity with adjustment to crystal-mobile and liquid-mobile particles:

$$
v_{2}=\frac{v_{r} T_{r}\left[\exp \left(-T_{m} / T_{r}\right)-\exp \left(-T_{b} / T_{r}\right)\right]}{T\left[\exp \left(-T_{m} / T\right)-\exp \left(-T_{b} / T\right)\right]},
$$

where $T_{m}$ and $T_{b}$ - melting and boiling temperature correspondingly.

Equation (3) represents the temperature dependence of kinematic viscosity with adjustment to all three types of particles:

$$
v_{3}=\frac{v_{r} T_{r}}{T} \exp \left(\frac{T_{m}}{T}-\frac{T_{m}}{T_{r}}\right) .
$$

However, it is necessary to develop a generalized viscosity model taking into account the degree of association of clusters of crystal-moving particles. 
These models have been tested on all the available reference material on the viscosity of metal melts.

The need to verify each of the three models of the viscosity and to select the most appropriate procedure complicates the data processing. This has prompted a closer look at the nature of the liquid state, while remaining within the concept of chaotized particles. It was found that the strong dependence on the temperature can be explained by the formation of aggregated or associated elementary cluster compounds. We propose a new model of viscosity:

$$
v=v_{r}\left(T_{r} / T\right)^{a} .
$$

Here the parameter $a$ makes meaning of the association degree $n$-partial cluster compounds [2].

\section{Experimental}

This section is devoted to the studies of the temperature dependence of the viscosity of the pure metals melts for which there are reference data. During the experimental data selection we rested upon the monograph [3] and reference books by M.E. Drits [4] in two parts about the properties of the elements. But there were no data about some elements viscosity.

The [3] with the reference to [5] provides data on the kinematic viscosity for cuprum at different temperatures. Melting and boiling points were taken from the reference book [4]. Their respective values are as follows: $T_{m}=1356 \mathrm{~K}$ and $T_{b}=2846 \mathrm{~K}$. We applied the closer data to the melting point $T_{r}=1438 \mathrm{~K}$ and $v_{r}=4.85 \cdot 10^{-7} \mathrm{~m}^{2} / \mathrm{s}$ as the fixed reference point. The viscosity calculation results for the four models are shown in Table 1 and Figure 1.

Table 1

\section{Comparison of experimental data [3] with the values of the kinematic viscosity of cuprum,} calculated by the models (1)-(4), $v \cdot 10^{7}, \mathrm{~m}^{2} / \mathrm{s}$

\begin{tabular}{|c|c|c|c|c|c|c|}
\hline$T$ & $v(\exp )$ & $v(1)$ & $v(2)$ & $v(3)$ & $a$ & $v(4)$ \\
\hline$T_{m}=1356$ & - & 5.14 & 5.27 & 5.44 & - & 5.34 \\
\hline 1438 & 4.85 & 4.85 & 4.85 & 4.85 & - & 4.85 \\
\hline 1568 & 4.05 & 4.45 & 4.33 & 4.11 & 2.08 & 4.20 \\
\hline 1653 & 3.84 & 4.22 & 4.05 & 3.73 & 1.68 & 3.85 \\
\hline 1738 & 3.72 & 4.01 & 3.82 & 3.41 & 1.40 & 3.55 \\
\hline 1823 & 3.44 & 3.83 & 3.62 & 3.13 & 1.45 & 3.28 \\
\hline$T_{b}=2846$ & - & 2.45 & 2.43 & 1.54 & - & 1.57 \\
\hline$R$ & - & 0.610 & 0.898 & 0.872 & - & 0.952 \\
\hline
\end{tabular}

Table 1 and graphical comparison shows that the model (4) is more accurate to describe the temperature dependence.

The average value of $\bar{a}=1.65$.

The average value must be checked for representativeness by the criterion of homogeneity of the set and then used in equation (4) to obtain the calculated values and compare with the experimental ones by the correlation coefficient.

The statistical homogeneity of the obtained set of values is evaluated by the Nalimov criterion:

$$
\begin{aligned}
& r_{\max }=\frac{\left|\bar{x}-x_{\max }\right|}{S(x) \sqrt{\frac{n-1}{n}}} \leq r_{c r}, \\
& S(x)=\sqrt{\frac{\sum\left(x_{i}-\bar{x}\right)^{2}}{n-1}},
\end{aligned}
$$

where $x_{\max }$ - is the mini/max value of the set; $\bar{x}$ - is the average value; $S(x)$ - is the mean square error; $n-$ is the volume of the set.

We have met the homogeneity of the obtained range for $a$ under the Nalimov criterion: $S(x)=0.312$; $\underset{\max }{r_{\min }}=1.598<r_{c r}=1.688$. 
Model (4) can be used with a fixed reference point close to the melting temperature $T_{r}=1438 \mathrm{~K}$ in the kinematic viscosity of cuprum during the consideration of the association degree of cluster compounds as a generalized model of melt viscosity in the full temperature range:

$$
v=\left(0.080 / T^{1,65}\right) \pm 8.02 \cdot 10^{-9}, \mathrm{~m}^{2} / \mathrm{s} \text {. }
$$

The correlation coefficient of model (3) is 0.898 and of model (4) is 0.952 . The correlation coefficient of model (4) is higher; therefore it is advisable to use model (4) to calculate the viscosity. We can calculate the viscosity in the considered temperature range with the following equation:

$$
\eta=A \exp \left(\frac{E_{a}}{R T}\right),
$$

where $E_{a}$ - is the activation energy; $R$ - is the gas constant; $T$ - is the temperature; $A-$ is the constant proposed by Arrhenius.

The activation energy for the estimated data equals to $E_{a}=18450 \mathrm{~J} / \mathrm{mol}$, while the activation energy for the proposed model will be $E_{a}{ }^{\prime}=22133 \mathrm{~J} / \mathrm{mol}$

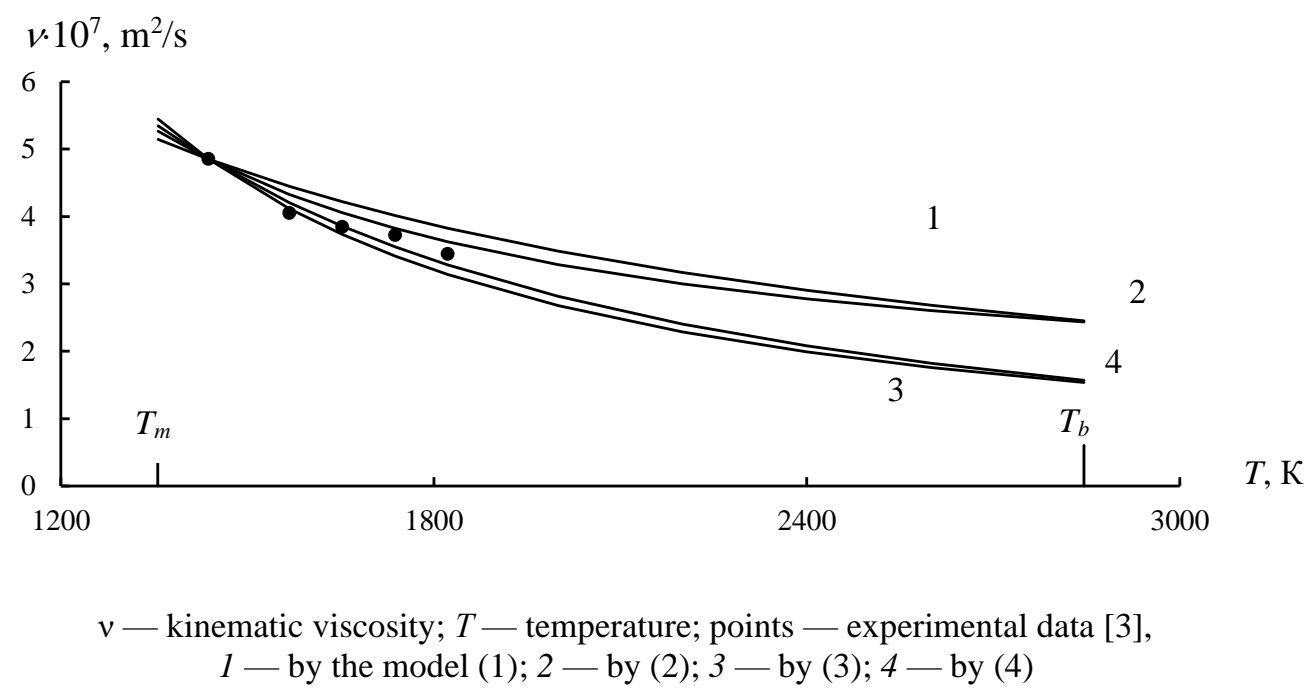

Figure 1. The temperature dependence of the kinematic viscosity of cuprum

Figure 2 shows the dependence of the logarithm of the kinematic viscosity of cuprum on the inverse temperature.

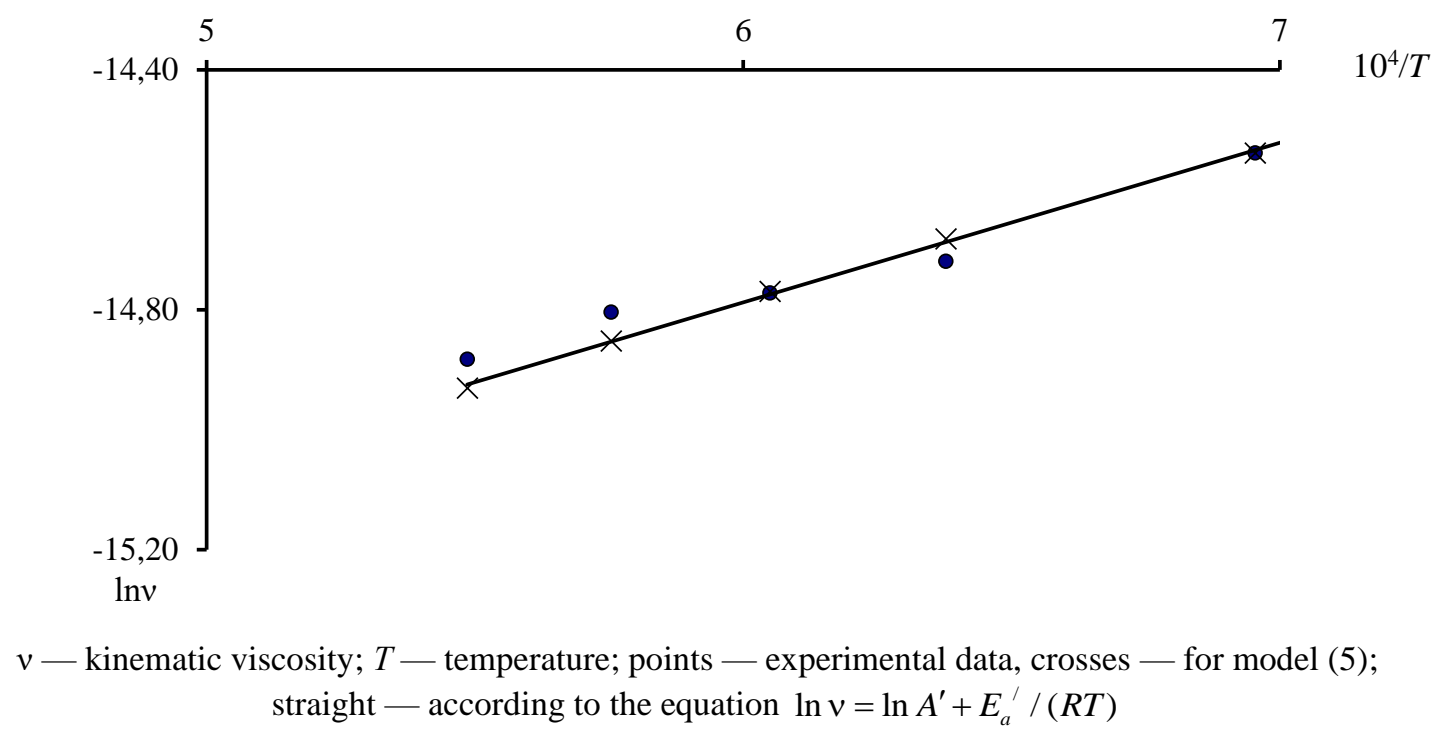

Figure 2. Logarithm dependence of the kinematic viscosity of cuprum on reverse temperature 


\section{Results and Discussion}

For magnesium the boiling and melting temperatures are known: $T_{m}=923 \mathrm{~K}, T_{b}=1380 \mathrm{~K}$. The values $T_{r}=973 \mathrm{~K}$ and $v_{r}=7.01 \cdot 10^{-7} \mathrm{~m}^{2} / \mathrm{s}$ are taken as a fixed reference point. The viscosity calculation results for the four models are shown in Table 2 and Figure 3.

Comparison of experimental data [3] with the values of the kinematic viscosity of magnesium, calculated by the models (1)-(4), $v \cdot 10^{7}, \mathrm{~m}^{2} / \mathrm{s}$

\begin{tabular}{|c|c|c|c|c|c|c|}
\hline$T$ & $v(\exp )$ & $v(1)$ & $v(2)$ & $v(3)$ & $a$ & $v(4)$ \\
\hline$T_{m}=923$ & 8.33 & 7.390 & 7.467 & 7.779 & - & 8.026 \\
\hline 973 & 7.010 & 7.010 & 7.010 & 7.010 & - & 7.010 \\
\hline 1073 & 5.420 & 6.357 & 6.288 & 5.819 & 2.629 & 5.453 \\
\hline 1173 & 4.390 & 5.815 & 5.745 & 4.946 & 2.504 & 4.339 \\
\hline$T_{b}=1380$ & - & 4.943 & 4.967 & 3.736 & - & 2.859 \\
\hline$R$ & - & 0.609 & 0.668 & 0.934 & - & 0.922 \\
\hline
\end{tabular}

From the Table 2 and graphical comparison it can be seen that the model (4) is more accurate in describing the temperature dependence.

The average value of $\bar{a}=2.57$. The increased degree of cluster association of metal atoms is a consequence of the fact that, against the background of the ionic structure of metal melts, it is possible to form molecular covalent bonds in them.

The uniformity of the obtained set for the Nalimov criterion is observed: $S(x)=2.568 ; r_{\max }=0.035<$ $<r_{c r}=1.483$.

Model (4) can be used with a fixed reference point close to the melting temperature $T_{r}=973 \mathrm{~K}$ in the kinematic viscosity of magnesium during the consideration of the association degree of cluster compounds as a generalized model of melt viscosity in the full temperature range:

$$
v=\left(0.337 \cdot 10^{2} / T^{2,57}\right) \pm 4.47 \cdot 10^{-9}, \mathrm{~m}^{2} / \mathrm{s} .
$$

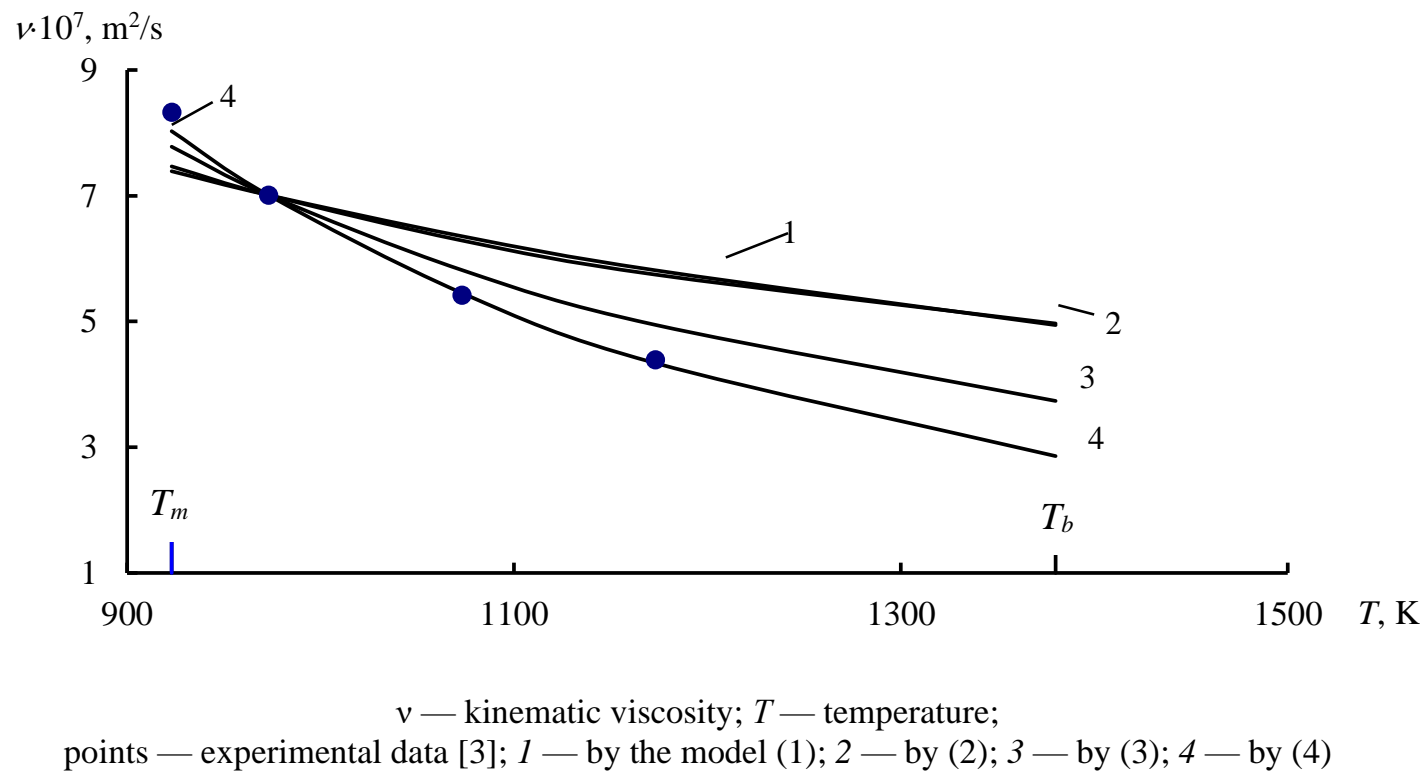

Figure 3. The temperature dependence of the kinematic viscosity of magnesium

According to equation (6), the activation energy is $E_{a}=22915 \mathrm{~J} / \mathrm{mol}$, but it is $E_{a}^{\prime}=22150 \mathrm{~J} / \mathrm{mol}$ for the proposed model. Figure 4 shows the logarithmic dependence of the magnesium viscosity on the inverse temperature. 


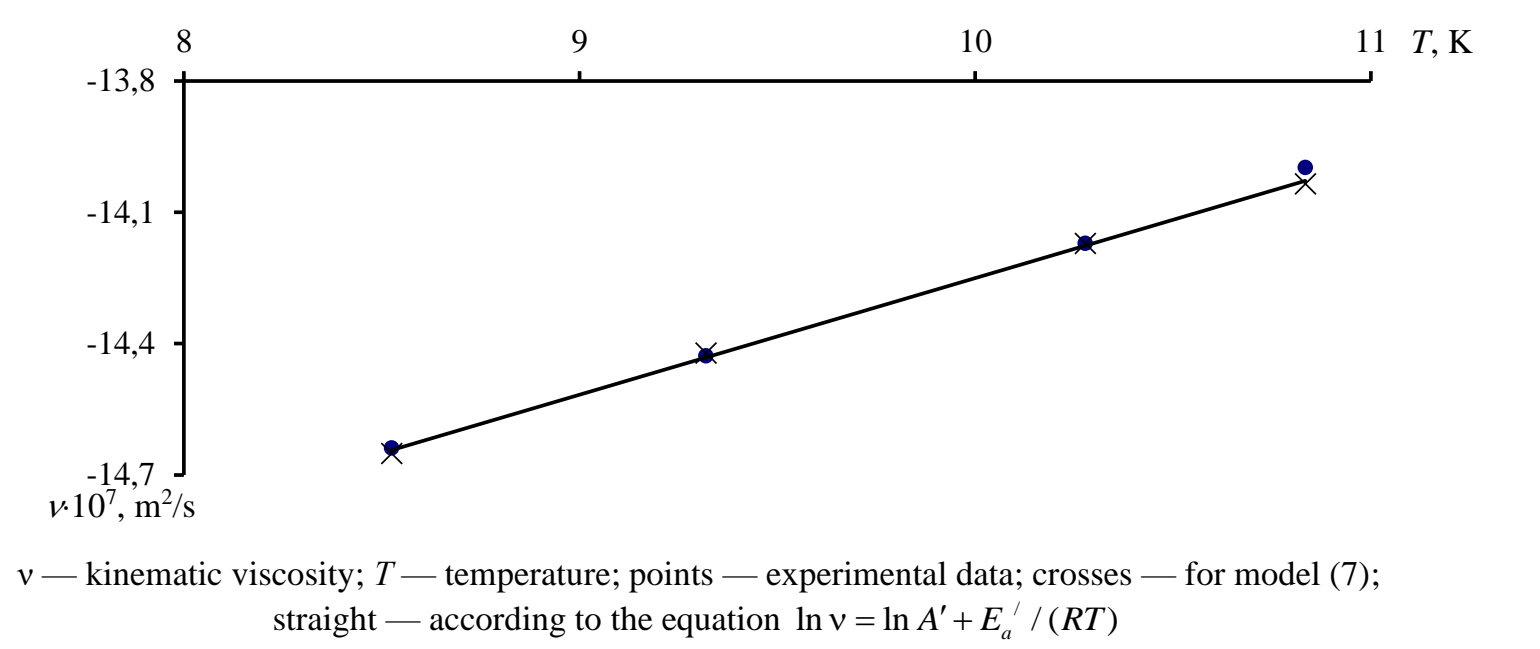

Figure 4. Logarithm dependence of the kinematic viscosity of magnesium on the inverse temperature

The melting and boiling temperatures of barium were taken from the reference book [4] and draw up $T_{m}=983 \mathrm{~K}$ and $T_{b}=1913 \mathrm{~K}$. In the monograph [3] with reference to the source [6], smoothed experimental data on the kinematic viscosity of barium are presented.

The fixed reference points was taken under $T_{r}=1073 \mathrm{~K}$ and $v_{r}=4.564 \cdot 10^{-7} \mathrm{~m}^{2} / \mathrm{s}$. The calculation results for the four models are shown in Table 3 and Figure 5.

Table 3

Comparison of experimental data [3] with the values of the kinematic viscosity of barium, calculated by the models (1)-(4), $v \cdot 10^{7}, \mathrm{~m}^{2} / \mathrm{s}$

\begin{tabular}{|c|c|c|c|c|c|c|}
\hline$T$ & $v(\exp )$ & $v(1)$ & $v(2)$ & $v(3)$ & $a$ & $v(4)$ \\
\hline$T_{m}=983$ & - & 4.982 & 5.134 & 5.418 & - & 5.234 \\
\hline 1073 & 4.564 & 4.564 & 4.564 & 4.564 & - & 4.564 \\
\hline 1173 & 3.901 & 4.175 & 4.089 & 3.861 & 1.762 & 3.971 \\
\hline 1373 & 3.067 & 3.567 & 3.440 & 2.920 & 1.612 & 3.105 \\
\hline 1473 & 2.793 & 3.325 & 3.210 & 2.592 & 1.550 & 2.782 \\
\hline 1573 & 2.577 & 3.113 & 3.022 & 2.327 & 1.494 & 2.510 \\
\hline 1773 & 2.264 & 2.762 & 2.732 & 1.924 & 1.396 & 2.082 \\
\hline$T_{b}=1913$ & - & 2.560 & 2.578 & 1.712 & - & 1.849 \\
\hline$R$ & - & 0.789 & 0.865 & 0.959 & - & 0.993 \\
\hline
\end{tabular}

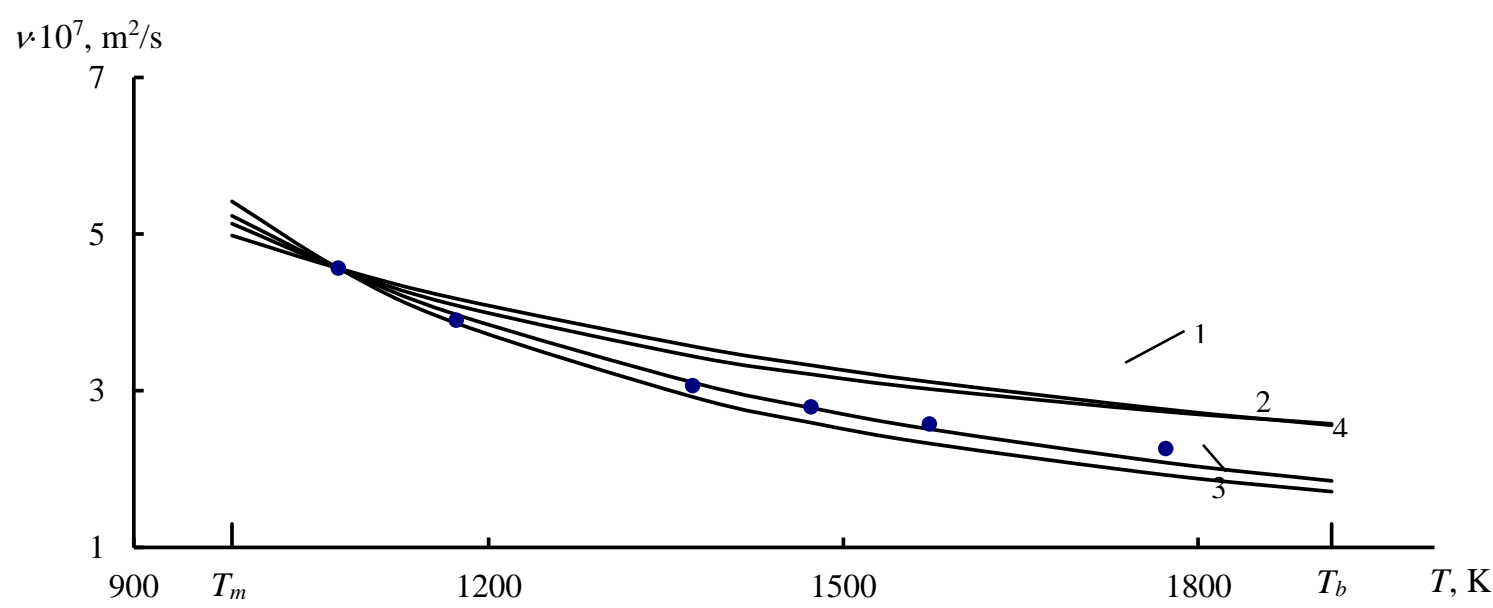

$v$ - kinematic viscosity; $T$ - temperature; points - experimental data [4];

1 - by the model (1);2 - by (2); 3 - by (3); 4 - by (4)

Figure 5. Temperature dependence of the kinematic viscosity of barium 
Table 3 shows that the experimental values and those calculated by model (4) are close. The Figure 6 also shows that the model (4) is more adequate in describing the temperature dependence of barium viscosity.

The average value $\bar{a}=1.56$.

We can see the uniformity of the obtained set for the Nalimov criterion as follows: $S(x)=0.137$; $r_{\min }=1.365<r_{c r}=1.821$.

Then considering the association degree of cluster compounds as a generalized model of melt viscosity in the full temperature range it is possible to use the model (4) with a fixed reference point close to the melting temperature $T_{r}=1073 \mathrm{~K}$ in the kinematic viscosity of barium finding a confidence interval and rounding-off:

$$
v=\left(0.0249 / T^{1,56}\right) \pm 1.68 \cdot 10^{-9}, \mathrm{~m}^{2} / \mathrm{s} \text {. }
$$

At the temperature range under consideration, the activation energy was calculated as $E_{a}=15889 \mathrm{~J} / \mathrm{mol}$, but it is $E_{a}^{\prime}=17543 \mathrm{~J} / \mathrm{mol}$ for the generalized model. Logarithm dependence of barium viscosity on the inverse temperature is presented in Figure 6.

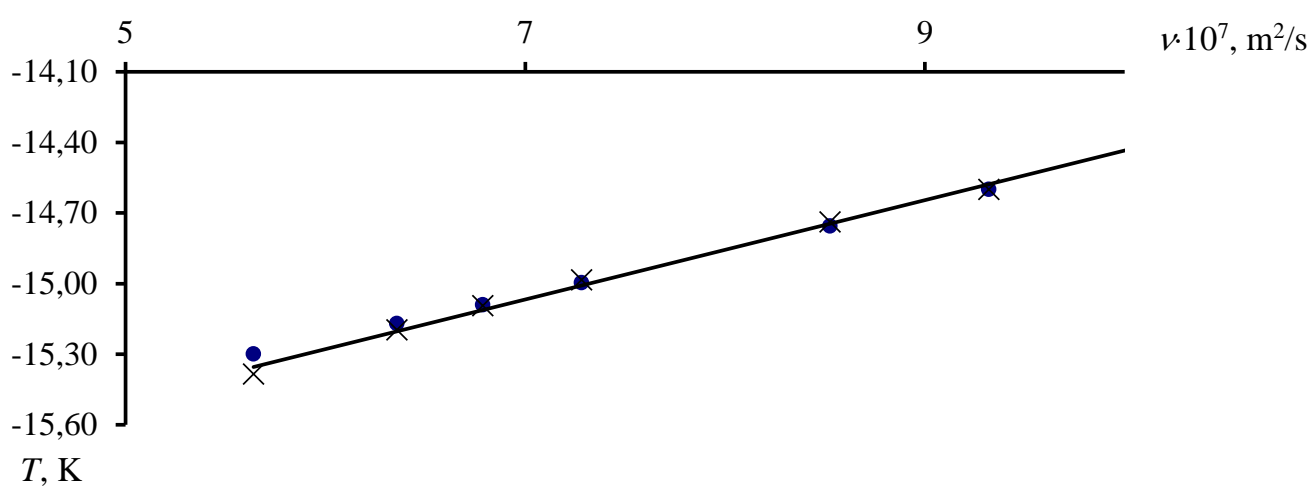

$v$ - kinematic viscosity; $T$ - temperature; points — experimental data; crosses — for model (8); straight — according to the equation $\ln v=\ln A^{\prime}+E_{a}^{\prime} /(R T)$

Figure 6. Logarithm dependence of the kinematic viscosity of barium on the inverse temperature

\section{Conclusions}

If unstable solid nuclei - clusters consisting of a complex of crystal-mobile particles exist in the melt, they are the ones to prevent the fluidity of metals. Thus, the viscosity of a liquid and its dependence on temperature can be estimated through the clusters. This was the basis for generating a new semi-empirical generalized model of the temperature-dependant viscosity of liquid metals having regard to both the formation of clusters and the degree of their associativity, that is the stronger role of crystal-mobile particles.

Therefore, this model determines the viscosity over a wide temperature range.

The new semi-empirical model of viscosity has been tried out on 3 typical metals, for which the reference data on the temperature dependence of viscosity are available. In the majority of cases, the generalized model describes the temperature dependence of viscosity more adequately through the comparison with the experimental data.

\section{References}

1 Малышев В.П. Вязкость расплавов по концепции хаотизированных частиц / В.П. Малышев, А.М. Турдукожаева, А.Ш. Кажикенова // Тяжелое машиностроение. — 2009. — № 6. — С. 37-39.

2 Kazhikenova A.Sh. Efficiency of applying cluster-associated model of viscosity of liquid metals / A.Sh. Kazhikenova, D.B. Alibiyev, E.S. Ibrayeva // Bulletin of the Karaganda University. Chemistry Series. — 2017. — No. 4(88). — P. 58-64.

3 Шпильрайн Э.Э. Исследование вязкости жидких металлов / Э.Э. Шпильрайн, В.А. Фомин, С.Н. Сковородько, Г.Ф. Сокол. - М.: Наука, 1983. — 247 с.

4 Свойства элементов: справоч. изд. [В 2 кн.]. - Кн. 1 / под ред. М.Е. Дрица. - 3-е изд., перераб. и доп. - М.: Изд. дом «Руда и металлы», 2003. - 448 с. 
5 Вертман А.А. К проблеме металлических расплавов / А.А. Вертман // Фундаментальные исследования физикохимии металлических расплавов. Памяти акад. А.М. Самарина. — М.: РКЦ «Академкнига», 2001. — 209 с.

6 Shpilrain E.E. Termo physical properties of liquid barium / E.E. Shpilrain, V.A. Fomin, D.N. Kagan, G.F. Sokol et al. // High Temp-High Press - 1977. - Vol. 9. - P. 45-56.

\author{
А.Ш. Қажикенова, Д.Б. Алибиев, А.Б. Сейтимбетова, А.С. Смаилова
}

\author{
Кинематикалық тұтқыр сұйық металға \\ кластерлі-ассоциативті модельді қолданудың тиімділігі
}

\begin{abstract}
Металл қорытпалары халық шаруашылығында және өнеркәсіпте жиі қолданылады. Сондықтан металдардың физика-химиялық қасиеттерін зерттеуге үлкен көңіл бөлінеді. Әсіресе зерттеушілер тұтқырлықты зерттеуге көп көңіл бөледі, себебі тұтқырлықтың металлургияда практикалық маңызы зор. Балқытылған металдың тұтқырлығын зерттеу үлкен ғылыми қызығушылық тудырады, сонымен қатар, тұтқырлық балқыманың құрылымдық-сезімталдық сипаттамасы болып табылады. Эксперимент арқылы тұтқырлықты зерттеу біршама қиын: көптеген металдар өте жоғары температураларда балқиды. Арнайы жабдықтарсыз мұндай жағдайларды жасау қиын. Сондықтан көптеген зерттеушілер тұтқырлықты түсінуге балама тәсілдер негізінде қосымша әзірлемелерді іздейді. Авторлар мақалада хаотизацияланған бөлшектердің жаңа концепциясын қарастырған және оның негізінде эксперимент жүргізбей, тұтқырлықты есептеу үшін кластерлік-ассоциаттық модель ұсынған. Олар ұсынылған үлгі бойынша кейбір металдардың кинематикалық тұтқырлығын есептеу мысалдарын келтірген. Алынған нәтижелерде ұсынылған модель өте жоғары температура кезінде де тұтқырлықты есептеуге мүмкіндік береді. Алынған нәтижелерді эксперименталды деректермен салыстыру ұсынылған модельдің функционалдығын көрсетеді. Ұсынылған модельді кең температуралық диапазонда сұйық металдардың тұтқырлығын есептеу үшін пайдалануға болады. Сонымен қатар, мақалада балқыманың тұтқыр ағынының белсендіру энергиясын есептеу үшін осы модельді қолдану мүмкіндігі көрсетілген.
\end{abstract}

Кілт сөздер: тұтқырлық, ретсізделген бөлшектер, ассоцирленген кластердің дәрежесі, кластерлі-ассоциативті моделі, сұйық металдар, реперлік нүкте, кристаллқозғалысты бөлшектер, тұтқырлықтың температураға тәуелдігі.

\title{
А.Ш. Кажикенова, Д.Б. Алибиев, А.Б. Сейтимбетова, А.С. Смаилова \\ Применение кластерно-ассоциатной модели для расчета кинематической вязкости расплавов металлов
}

\begin{abstract}
Расплавы металлов довольно часто используются в народном хозяйстве и промышленности. Поэтому исследованию физико-химических свойств металлов уделяется большое внимание. Особый интерес вызывает изучение вязкости, ввиду того, что она имеет большое практическое значение в металлургии. Изучение вязкости расплавленного металла в то же время представляет и научный интерес, так как является наиболее структурно-чувствительной характеристикой расплава. Изучение вязкости с помощью эксперимента несколько затруднено: многие металлы плавятся при очень высоких температурах. Создать такие условия без специального оборудования сложно. По этой причине многие исследователи ищут дополнительные разработки на основе альтернативных подходов к пониманию вязкости. Авторы данной статьи рассмотрели новую концепцию хаотизированных частиц и на ее основе предложили кластерно-ассоциатную модель для расчета вязкости без проведения эксперимента. Они привели примеры расчета кинематической вязкости некоторых металлов по предложенной модели. Полученные результаты показывают, что данная модель позволяет вычислить вязкость даже при очень высоких температурах. Сопоставление полученных результатов с экспериментальными данными указывает на функциональность предлагаемой модели, которую можно использовать для расчета вязкости жидких металлов в широком температурном диапазоне. Также в статье показана возможность применения данной модели для расчета энергии активации вязкого течения расплава.
\end{abstract}

Ключевые слова: вязкость, хаотизированные частицы, степень ассоциированности кластеров, кластерно-ассоциатная модель, жидкие металлы, реперная точка, кристаллоподвижные частицы, температурная зависимость вязкости. 


\section{References}

1 Malyshev, V.P., Turdukozhaeva, A.M., \& Kazhikenova, A.Sh. (2009). Viazkost rasplavov po kontseptsii khaotizirovannykh chastits [The viscosity of the molten metal on the concept of randomized particles]. Tiazheloe mashinostroenie - Heavy Engineering, 6, 37-39 [in Russian].

2 Kazhikenova, A.Sh., Alibiyev, D.B., \& Ibrayeva, E.S. (2017). Efficiency of applying cluster-associated model of viscosity of liquid metals. Bulletin of the Karaganda University, Chemistry Series, 4(88), 58-64.

3 Schpilrain, E.E., Fomin, V.A., Skovorodko, S.H., \& Sokol, G.F. (1983). Issledovanie viazkosti zhidkikh metallov [Viscosity study of liquid metals]. Moscow: Nauka [in Russian].

4 Drits, M.E. (Eds.). (2003). Svoistva elementov [The properties of the elements]. (Books 1-2). Moscow: Izdatelskii dom "Ruda i metally" [in Russian].

5 Vertman, A.A. (2001). K probleme metallicheskikh rasplavov [On the problem of metal melts]. Fundamentalnye issledovaniia fizikokhimii metallicheskikh rasplavov. Pamyati akademika A.M. Samarina - Fundamental studies of physical chemistry of metal melts. In memory of Academician A.M. Samarin. Moscow: Akademkniha [in Russian].

6 Shpilrain, E.E., Fomin, V.A., Kagan, D.N., \& Sokol G.F. et al. (1977). Termo physical properties of liquid barium. High TempHigh Press, 9, 45-56. 